\title{
HUBUNGAN PEMBELAJARAN PENDIDIKAN AGAMA ISLAM (PAI) DENGAN PEMAHAMAN JIWA KEAGAMAAN SISWA DI BENGKULU SELATAN
}

\author{
${ }^{1}$ Pasmah Chandra, ${ }^{2}$ Della Carolina \\ ${ }^{1 .}$ IAIN Bengkulu, ${ }^{2}$ STIT Al-Quraniyah Manna \\ 1.pasmah@iainbengkulu.ac.id ${ }^{2 \cdot d e l l a c a r o l i n a @ g m a i l . c o m ~}$
}

\begin{abstract}
Islamic religious education taught in schools is an important subject for students. Islamic Religious Education does not only cover cognitive sense in the form of knowledge and material, but more broadly covers the psychomotor domain and especially the affective domain which leads to the formation of student morals. Even Islamic Religious Education instilled in students must be able to form a strong understanding of the religious soul in students. Some previous studies have not touched on the level of understanding of the religious soul in students as a result of Islamic Religious Education. Previous studies only discussed the extent of Islamic Religious Education is relationship with the formation of students' character or character. The purpose of the research is to find out the relationship of Islamic Religious Education learning with the understanding of students' religious souls. The research method that I use is a type of quantitative research using the product moment formula and the data collection tools used in the form of observation, interviews, documentation and questionnaires. The sample in this study amounted to 36 people. Based on the results of research and calculations with an error level of 5\% (trust) and $\mathrm{N}(36)$, then $\mathrm{r}$ table $=0.329$. Then the price $r$ count is greater than $r$ table or $0.696>0.329$. Thus the results were obtained that $\mathrm{H}_{0}$ was rejected and Ha was accepted, meaning that there was a relationship between Islamic religious education learning and the understanding of the religious life of students of class sains in senior high school of 05 Bengkulu Selatan.
\end{abstract}

Keywords: Islamic Religious Education Learning, Understanding of the Soul of Religion

\begin{abstract}
ABSTRAK
Pendidikan agama Islam (PAI) yang diajarakan di sekolah merupakan mata pelajaran penting bagi siswa. PAI tidak hanya mencakup rasa kognitif saja berupa pengetahuan dan materi, melainkan lebih luas mencakup ranah psikomotor dan terutama ranah afektif yang bermuara pada pembentukan akhlak siswa. Bahkan PAI yang ditanamkan pada siswa harus mampu membentuk pemahaman jiwa keagamaan yang kuat pada siswa. PAI harus tercermin pada perilaku keseharian dengan tindakan atau perbuatan. Beberapa studi terdahulu belum menyentuh pada tingkatan pemahaman jiwa keagamaan pada siswa sebagai efek dari PAI. Studi terdahulu hanya membahas sebatas hubungan PAI dengan pembentukan akhlak atau karakter siswa. Adapun tujuan dari penelitian ialah untuk mengetahu hubugan pembelajaran PAI dengan pemahaman jiwa keagamaan siswa. Metode Penelitian yang penulis gunakan adalah jenis penelitian kuantitafif dengan menggunakan rumus korelasi product moment dan dengan alat pengumpulan data yang digunakan berupa observasi, wawancara, dokumentasi serta angket. Sampel dalam penelitian ini berjumlah 36 orang. Berdasarkan hasil penelitian dan perhitungan dengan taraf kesalahan $5 \%$ (kepercayaan) dan $N$ (36), maka $r$ tabel $=0,329$. Maka harga $r$ hitung lebih besar dari $r$ tabel atau 0,696 $>0,329$. Dengan demikian diperoleh hasil bahwa $\mathrm{H}_{0}$ ditolak dan $\mathrm{Ha}$ diterima, artinya ada hubungan antara pembelajaran pendidikan Agama Islam dengan pemahaman jiwa agama siswa kelas XI IPA di SMA Negeri 05 Bengkulu Selatan.
\end{abstract}

Kata Kunci : Pembelajaran Pendidikan Agama Islam, Pemahaman Jiwa Keagmaan 


\section{PENDAHULUAN}

Perkembangan jasmani pada anak Sekolah Menengah Atas (SMA) berjalan dengan cepat terutama pada rentang umur antara 16-18 tahun. Selain itu juga, yang terpenting ialah mengenai pemahaman jiwa agama pada masa-masa tersebut.(Nasrudin, 2017: 35) Apabila mereka telah memahami ajaran agamanya dan telah terbiasa berdoa dan melakukan ibadah, serta menerapkan ketentuan agama dalam kehidupan sehari-hari sebelum memasuki umur produktif, maka permasalahan pembinaan akan akhlak dan aspek lainnya akan mudah. Hal ini dikarenakan mereka sudah terbiasa mematuhi perintah agama dan menjauhi larangannya. Misalnya saja, dorongan seks yang mereka rasakan secara samar itu dapat diabaikan dan dikendalikan. Kecemasan dan kegoncangan jiwa yang terjadi akibat perasaan jiwa yang tertekan atau tidak puas, dapat mereka ungkapkan kepada Allah di dalam doa dan sholatnya, karena jiwanya merasa dekat dengan Allah SWT.(Jannah, 2017: 15)

Deskripsi tersebut menjelaskan bahwa pendidikan agama berperan amat penting dalam mengimbangkan suasana jiwa keagamaan anak ditengah-tengah terjadinya pemahaman dirinya yang lain. Karena pendidikan Agama Islam merupakan ilmu pengetahuan untuk membentuk indiviu bercorak diri berderajat tinggi manurut ukuran Allah SWT.(Hendriana \& Jacobus, 2017: 78) Namun, betapapun mulia dan tingginya kedudukan ilmu pengetahuan, semuanya kembali kepada seseorang yang memiliki ilmu pengetahuan itu, bagaimana ia menempatkan ilmu pengetahuan sebagai bagian dari kehidupannya, mengimplementasikan atau mengamalkannya. Apabila ilmu yang telah dikuasainya tidak bermanfaat bagi dirinya maupun orang lain, berarti ia telah sia-sia dengan ilmunya dengan kata lain tujuan pendidikan sejatinya tidak dipahami, yakni menjadikan anak saleh dengan rohaniah yang sehat, dapat mengendalikan emosi, memiliki perilaku sosial yang baik, cerdas, dan penuh vitalitas, berjiwa suci dan bersih.(Wedan, 2016: 55) Secara psikologis orang-orang dengan ilmu tinggi tetapi pengimplementasi meleset dari tujuan pendidikan, berarti orang tersebut sedang mengalami hambatan psikologis.(Diananda, 2019: 47)

Pendidikan agama sangat besar perannya dalam membentuk sikap dan pribadi keagamaan individu atau anak-anak didik.(Ahmad, 2018) Maka untuk mewujudkan manusia Indonesia yang beriman dan bertaqwa sebagaimana yang dirumuskan dalam tujuan pendidikan nasional maka salah satunya dengan melaksanakan pendidikan agama, karena pendidikan agama memiliki jangkauan yang menyeluruh terhadap seluruh aspek. Pendidikan agama yang dilaksanakn secara formal di sekolah, pada prinsipnya bertujuan untuk membentuk pribadi anak yang memiliki keimanan dan ketaqwaan yang tinggi, atas dasar 
keimanan yang dimiliki itu anak didik bersikap dan bertingkah laku yang mencerminkan pendidikan agama.(Arif, 2011: 25)

Tujuan pendidikan Islam secara garis besarnya adalah membina manusia agar menjadi hamba Allah yang sholeh dengan seluruh aspek kehidupan, perbuatan, pikiran, dan perasaannya.(Syafe'i, 2015: 113) Pendidikan agama merupakan bagian terpenting yang harus dilaksanakan dalam rangka meningkatkan keimanan dan ketaqwaan peserta didik untuk menjadi manusia yang berakhlak mulia (bermoral).(Hakim, 2012: 78) Dengan demikian pelaksanaan kurikulum pendididikan agama di sekolah diharapkan mampu mengahasilkan peserta didik yang benar-benar memiliki keimanan yang kuat dan ketaqwaan yang tinggi dengan dilandasi oleh akhlak mulia sehingga dapat diimplementasikan dalam kehidupan sehari-hari.

Pendidikan Agama Islam memberikan keyakinan dalam hal agama, serta nilai sosial yang mencakup nilai-niali budaya dan aturan pergaulan serta pandangan, keterampilan dan sikap hidup yang mendukung skehidupan bermasyarakat, berbangsa dan bernegara kepada anggota keluarga yang bersangkutan.(Nurmadiah, 2016: 61) Pendidikan agama islam memperbaiki akhlak anak-anak, membersihkan hati, dan mensucikan jiwa mereka, agar berkepribadian baik dalam kehidupannya serta anak-anak menjadi mengetahui dan mengerti akan kewajiban sebagai umat beragama, sehinnga ia mengikuti aturan yang telah ditetapkan dan menajuhi dari larangan Agama Islam. Artinya melalui pendidikan agama Islam di sekolah diharapakan siswa agar menjadi orang yang disiplin, mempunyai kepribadian yang kuat dan sikap mental yang sehat, serta akhlak perilaku yang terpuji.(Hamzah, 2015: 89)

Pendidikan Agama Islam takkan tersampaikan dengan sempurna apabila proses pembelajaran berlangsung membosankan. Proses pembelajaran harus mempertimbangkan segi psikologis anak seperti: kesiapan fisik, kesiapan mental dan kognitif.(Ahmad, 2018: 77) Kesiapan fisik meliputi keadaan fisik yang sehat dan kuat tidak dalam keadaan sakit dan lemah. Di sini pendidik harus jeli menilai keadaan fisik peserta didiknya ketika pembelajaran berlangsung. Kesiapan mental meliputi keterampilan dan keberanian peserta didiknya ketika pembelajaran berlangsung. Kesiapan mental meliputi keterampilan, percaya terhadap dirinya sendiri dan keberanian peserta didik dalam berinteraksi saat pembelajaran berlangsung, seperti bertanya dan menyampaikan jawaban.(Soebiantoro, 2017: 21) Suasana kelas akan terasa mati jika peserta didik takut menyampaikan pertanyaan atau takut salah menjawab ketika ditanya terkait materi yang sedang diajarkan. Kognitif siswa adalah berpikir sisa dalam belajar. Bahwa tidak semua siswa di dalam kelas memiliki kepandaian dan kecerdasan yang sama.(Nyumirah, 2013: 40) Menghadapi perbedaan kecerdasan yang dimiliki siswa sudah 
tentu menuntut suatu cara menyampaikan pelajaran yang bervariasi dan jika tidak tentu akan menimbulkan hambatan-hambatan belajar siswa.

Sasaran utama pembelajaran pendidikan Agama Islam ialah keimanan. Keimanan merupakan salah satu isi pendidikan Islam dan bersifat unik, yaitu bahwa menempatkan hubungan antara hamba dan al-Khaliq sebagai keutamaan. Karena dengan hubungan tersebut, kehidupan individu akan bermakna, perbuatannya akan bertujuan, dorongannya untuk belajar dan beramal akan tumbuh, akhlaknya menjadi mulia, dan jiwanya menjadi bersih, sehingga pada gilirannya akan memiliki kompetensi untuk menjadi khalifah di muka bumi ini.(Raharjo, 2010: 67) Artinya, produk sebagai keluaran dari pendidikan Agama Islam dan pendidikan Islam adalah tertanamnya jiwa keagamaan pada diri setiap anak. Seseorang yang memiliki jiwa keagaman dalam dirinya selaras antara tindakannya dengan prinsip agama yang dianutnya. Islam melarang menegakkan kebenaran dengan kekerasan atau meredam kekerasan. Kalau akhir-akhir ini terjadi tindak kekerasan dalam menegakkan kebenaran, artinya dalam diri orang-orang belum terjadi suatu sinergisitas antara kejiwaan dengan agamanya. Agama menyangkut kehidupan batin manusia. Oleh karena itu kesadaran agama dan pengalaman agama seseorang lebih menggambarkan sisi-sisi batin dalam kehidupan yang ada kaitannya dengan sesuatu yang sakral. Dari kesadaran agama dan pengalaman agama ini pula kemudian muncul sikap keagamaan yang ditampilkan seseorang.

Pendidikan agama Islam yang dilaksanakan di SMA Negeri 05 Bengkulu Selatan tujuannya sama yaitu pananaman keimanan kepada siswa walaupun materi pembelajaran meliputi berbagai aspek seperti ibadah, dan akhlak. Internalisasi terhadap kedua aspek ini oleh siswa dalam kehidupannya sehari-hari menjadi kadar keimanan mereka. ${ }^{1}$ Pendidikan agama di lembaga bagaimanapun akan memberi hubungan bagi pembentukan jiwa keagamaan pada anak. Namun demikian, besar kecilnya hubungan dimaksud sangat tergantung berbagai faktor yang dapat memotivasi anak untuk memahami nilai-nilai agama. Sebab pendidikan agama pada hakikatnya merupakan pendidikan nilai-nilai Islami yang dapat memberikan hubungan terhadap jiwa agama seseorang. Oleh karena itu pendidikan agama lebih dititiberatkan pada bagaimana membentuk kebiasaan yang selaras dengan tuntunan agama.(Nidawati, 2013: 68)

Jiwa agama itu sendiri bukan sesuatu yang dicerminkan oleh sifat kebendaan, melainkan sesuatu yang bersifat ilahiah, yaitu sesuatu yang disadarinya untuk berbuat sesuatu yang bersumber kepada kesbaikan sebagai simbol ketuhanan melalui cipta, karsa, dan

${ }^{1}$ Wawancara dengan Guru Pendidikan Agama Islam (Ibu Yuni Kurniawati) SMAN 05 B/S, Kamis 18 Juli 2019 pukul 10.00 WIB , di ruang guru. 
rasa.(Mustafa, 2016: 93). Apakah jiwa agama yang direpresentasikan melalui cipta, karsa, dan rasa ini ada di dalam diri siswa, khususnya siswa SMA Negeri 05 Bengkulu Selatan? Pengamatan awal peneliti memberikan suatu gambaran bahwa permasalahan jiwa agama siswa sangat memungkinkan berkembang lebih baik lagi. Dari segi cipta yang bertumpu kepada akal pikiran siswa dapat mengambil sikap dalam menentukan benar tidaknya ajaran suatu agama. Berpijak atas pertimbangan cipta atau pikiran ini, tampak dimana siswa meyakini Islam sebagai agama yang dianutnya terlepas apakah keyakinannya itu masih sebatas karena orang tuanya Islam. Dari segi rasa yang menunjukan emosi, mereka memiliki sikap batin yang seimbang dan positif dalam menghayati ajaran agama. Artinya, siswa menghayati ajaran agamanya dengan kesadaran batin tanpa keraguan dan secara rasa, mereka mengakui bahwa agama Islam yang dianutnya merupakan agama yang hak. Namun dari segi karsa, mereka belum dapat sepenuhnya melakukan amalan-amalan yang benar dan logis sehingga selaras kepada yang ia pahami dalam batas cipta dan rasa. Berdasarkan observasi yang peneliti lakukan, masih terdapat siswa yang melanggar peraturan sekolah. Misalnya, terlambat datang ke sekolah, membolos pada jam pelajaran, masih ada yang belum memiliki kesadaran tentang ibadah shalat yaitu shalat dzuhur. Selain itu juga, terdapat sikap tidak sopan yang dituangkan kepada guru. ${ }^{2}$

\section{METODE PENELITIAN}

Jenis penelitian ini menggunakan pendekatan kuantitatif yang menggunakan analisis data statistik. Penelitian kuantitatif merupakan suatu proses penelitian yang menghasilkan data berupa angka-angka, tulisan atau ungkapan yang di peroleh langsung dari lapangan atau wilayah penelitian.

Populasi dalam penelitian ini adalah siswa kelas XI IPA SMA Negeri 05 Bengkulu Selatan berjumlah sebanyak 180 orang. Sampel dalam penelitian ini adalah siswa. Teknik pengambilan sampel menggunakan teknik restricted sample; sampel terbatas yang penetapannya oleh kondisi-kondisi tertentu. Maka dalam penelitian ini, penulis mengambil sampel antara 10-15\%, atau 20-25\% atau lebih.(Sugiyono, 2018: 145) Jadi sampel yang peneliti pakai adalah $20 \%$ x 180 atau 0,20 x 180 hasilnya 36 responden.

Ada berberapa teknik yang penulis gunakan dalam pengumpulan data yaitu, pertama observasi, dalam penelitian ini, observasi peneliti gunakan untuk memperoleh gambaran yang nyata berkaitan dengan yang di teliti berkenaan dengan kondisi objektif lapangan dari pengamatan peneliti. Angket, instrument ini untuk mengetahui pendapat atau fakta bukan

\footnotetext{
${ }^{2}$ Observasi di SMAN 05 Bengkulu Selatan pada kelas XI IPA ,Sabtu 20 Juli 2019. Pukul 08.25 WIB
} 
pengukur kemampuan.Oleh karena itu jawaban yang diberikan kepada respponden tidak harus bervariasi.(Arikunto, 2010: 156) Skoring, diperlukan dalam upaya membuat sesuatu klarifikasi bobot terhadap item-item pertanyaan yang diajukan dalam kuesioner. Skor yang diberikan untuk setiap item jawaban pertanyaan sesuai dengan pilihan yang dipilih responden, sebagai berikut di mana konotatif jawaban bersifat positif dan negatif yang urutan penilaian atau penskorannya disajakan dalam tabel di bawah ini.

Dalam melakukan analisis data, penulis menggunakan teknik korelasi produkct moment. Digunakannya analisis dengan teknik ini karena variabel yang hendak diteliti yaitu: Hubungan Pembelajaran Pendidikan Agama Islam (X) dan Pemahaman Jiwa Agama Siswa (Y) memiliki jenis interval. Rumus korelasi product moment yang digunakan adalah:

$r=\frac{\mathrm{n}\left(\sum \mathrm{XY}\right)-\left(\sum \mathrm{X}\right)\left(\sum \mathrm{Y}\right)}{\left.\sqrt{\left\{\mathrm{n} \cdot \sum \mathrm{X}^{2}\right.}-\left(\sum \mathrm{X}\right)^{2}\right\}\left\{\mathrm{n} \cdot \sum \mathrm{Y}^{2}-\left(\sum \mathrm{Y}\right)^{2}\right\}}$

Keterangan:

$\mathrm{r}=$ Nilai relasi yang dicari

$\mathrm{n}=$ Jumlah responden

$\mathrm{X}=$ Total nilai setiap butir jawaban variabel $\mathrm{X}$

$\mathrm{Y}=$ Total nilai setiap butir jawaban variabel Y.(Suharsimi, 2013)

\section{HASIL DAN PEMBAHASAN}

\section{Deskripsi Data}

Untuk memperoleh data yang penulis lakukan yang berkaitan dengan judul penelitian yaitu tentang hubungan pembelajaran pendidikan agama Islam terhadap pemahaman jiwa agama siswa kelas XI IPA di SMA Negeri 05 Bengkulu Selatan. Peneliti memperoleh jawaban dengan menyebarkan angket kepada siswa yang berjumlah 36 orang yang menjadi sampel dalam penelitian ini. Penyajian data yang penulis buat dengan berbentuk data kuantitatif yang diperoleh dari skoring jawaban yang tersedia, sebagaimana yang telah penulis jelaskan pada bab sebelumnya bahwa setiap jawaban diberi skor tertinggi adalah 4 dan skor terendah adalah 0. Berdasarkan hasil pengolahan data yang telah dilakukan maka data tersebut dapat dideskripsikan adalah sebagai berikut:

\section{Pengujian Hipotesis}

\section{Masalah Pertama}

Pelaksanaan Pembelajaran Pendidikan Agama Islam Kelas XI IPA Di SMA Negeri 05 Bengkulu Selatan. 
Berdasarkan skor setiap alternatif yang diajukan, sebagaimana dijelaskan sebelumnya, maka untuk variable $\mathrm{X}$ (pembelajaran pendidikan agama islam) diajukan 16 pertanyaan, jadi jumlah skor berkisar 0 sampai 64 .

Untuk mengetahui hubungan pembelajaran pendidikan Agama Islam kelas XI IPA di SMA Negeri 05 Bengkulu Selatan. Dapat dianalisis terlebih dahulu dengan mencari kelas interval. Untuk mencari batas interval tersebut, digunakan rumus sebagai berikut:

$$
\begin{aligned}
\text { Interval } & =\frac{\text { Nilai tertinggi-Nilai terendah }}{\text { Alternatif yang diajukan }} \\
& =16 \times 4 \equiv 64 \\
\text { Interval } & =\frac{(64-0)}{5}=\mathbf{1 2 , 8}
\end{aligned}
$$

Dari perhitungan ini, maka diperoleh tingkat skor sebagai berikut:

Tabel 1.

Kelas Interval Hubungan Pembelajaran Pendidikan Agama Islam

Di SMA Negeri 05 Bengkulu Selatan

\begin{tabular}{ccc}
\hline N0 & Kelas Interval & Klasifikasi \\
\hline $\mathbf{1}$ & $0-12,8$ & Tidak baik \\
\hline $\mathbf{2}$ & $12,9-25,7$ & Kurang baik \\
\hline $\mathbf{3}$ & $25,8-38,6$ & Cukup baik \\
\hline $\mathbf{4}$ & $38,7-51,5$ & Baik \\
\hline $\mathbf{5}$ & $51,6-64,4$ & Sangat baik \\
\hline
\end{tabular}

Dari tabel 1 dapat dilihat bahwa pembelajaran pendidikan agama Islam (variable x) nilai rata-ratanya adalah 50,277 bila dicocokkan pada r tabel, maka dapat diketahui bahwa klasifikasinya baik.

Tabel 2.

Skor Jawaban Angket Hubungan Pembelajaran Pendidikan Agama Islam di SMA Negeri 05 Bengkulu Selatan

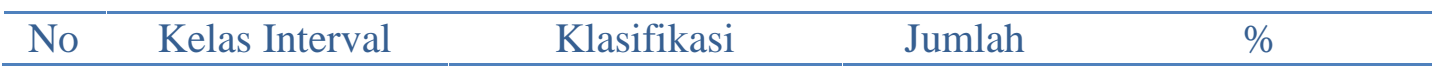




\begin{tabular}{ccccc}
\hline $\mathbf{1}$ & $0-12,8$ & Tidak baik & - & - \\
$\mathbf{2}$ & $12,9-25,7$ & Kurang baik & - & - \\
$\mathbf{3}$ & $25,8-38,6$ & Cukup baik & - & - \\
$\mathbf{4}$ & $38,7-51,5$ & Baik & 20 & $55,556 \%$ \\
$\mathbf{5}$ & $51,6-64,4$ & Sangat baik & 16 & $44,444 \%$ \\
\hline
\end{tabular}

Dari tabel 2 dapat dilihat bahwa hubungan pembelajaran pendidikan Agama Islam di SMA Negeri 05 Bengkulu Selatan yang menjawab baik sebesar 55,556 \% dan 44,444 \% di kategorikan sangat baik sedangkan yang berpendapat hubungan pembelajaran pendidikan Agama Islam yaitu tidak baik, kurang baik dan cukup baik tidak ada.

\section{Masalah Kedua}

Pemahaman Jiwa Agama Siswa Kelas XI IPA Di SMA Negeri 05 Bengkulu Selatan.

Berdasarkan skor setiap alternatif yang diajukan, sebagaimana dijelaskan sebelumnya, maka untuk variabel Y (pemahaman jiwa agama) yang diajukan 16 pertanyaan, jadi jumlah skor berkisar 0 sampai 64 .

Untuk mengetahui pemahaman jiwa agama siswa kelas XI IPA di SMA Negeri 05 Bengkulu Selatan. Dapat dianalisis terlebih dahulu dengan mencari kelas interval. Untuk mencari batas interval tersebut, digunakan rumus sebagai berikut:

$$
\begin{aligned}
& \text { Interval }=\frac{\text { Nilai tertinggi-Nilai terendah }}{\text { Alternatif yang diajukan }} \\
& X \quad=16 \times 4=64 \\
& \text { Interval }
\end{aligned}
$$$$
5
$$

Dari perhitungan ini, maka diperoleh tingkat skor sebagai berikut:

Tabel 3 .

Kelas Interval Pemahaman Jiwa Agama

Di SMA Negeri 05 Bengkulu Selatan

\begin{tabular}{ccc}
\hline N0 & Kelas Interval & Klasifikasi \\
\hline $\mathbf{1}$ & $0-12,8$ & Tidak baik \\
\hline $\mathbf{2}$ & $12,9-25,7$ & Kurang baik \\
\hline $\mathbf{3}$ & $25,8-38,6$ & Cukup baik \\
\hline $\mathbf{4}$ & $38,7-51,5$ & Baik \\
\hline $\mathbf{5}$ & $51,6-64,4$ & Sangat baik \\
\hline
\end{tabular}


Dari tabel 3 dapat dilihat bahwa pemahaman jiwa agama (variabel y) nilai rata-ratanya adalah 44,361 bila dicocokkan pada $r$ tabel, maka dapat diketahui bahwa klasifikasinya baik.

Kalsifikasi skor tabel 4.13 dapat dikategorikan pada jumlah responden berikut:

Tabel 4 Skor Jawaban Angket Pemahaman Jiwa Agama Di SMA Negeri 05 Bengkulu Selatan

\begin{tabular}{ccccc}
\hline No & $\begin{array}{c}\text { Kelas } \\
\text { Interval }\end{array}$ & Klasifikasi & Jumlah & $\%$ \\
\hline $\mathbf{1}$ & $0-12,8$ & Tidak baik & - & - \\
$\mathbf{2}$ & $12,9-25,7$ & Kurang baik & - & - \\
$\mathbf{3}$ & $25,8-38,6$ & Cukup baik & - & - \\
$\mathbf{4}$ & $38,7-51,5$ & Baik & 24 & $66,667 \%$ \\
$\mathbf{5}$ & $51,6-64,4$ & Sangat baik & 12 & $33,333 \%$ \\
& & & 36 & $100 \%$ \\
\hline
\end{tabular}

Dari tabel 4 dapat dilihat bahwa pemahaman jiwa agama di SMA Negeri 05 Bengkulu Selatan yang menjawab baik sebesar 66,667 \% dan 33,333\% di kategorikan sangat baik sedangkan yang berpendapat pemahaman jiwa keagamaan yaitu tidak baik, kurang baik dan cukup baik tidak ada.

\section{Masalah Ketiga}

Apakah Ada Hubungan Pembelajaran Pendidikan Agama Islam Terhadap Pemahaman Jiwa Agama Siswa Kelas XI IPA Di SMA Negeri 05 Bengkulu Selatan? Untuk menjawab permasalahan tersebut yaitu sejauh mana hubungan antara variabel $\mathrm{X}$ dan variabel Y, digunakan rumus Product Moment sebagai berikut:

$$
r x y=\frac{n\left(\sum x \cdot y\right)-\left(\sum x\right)\left(\sum y\right)}{\sqrt{\left[n\left(\sum \mathbf{x}^{2}\right)-\left(\sum \mathbf{x}^{2}\right)\right]\left[n\left(\sum y^{2}\right)-\left(\sum y^{2}\right)\right]}}
$$

Keterangan:

Rxy = koefisien korelasi yang dicari

$\mathrm{N} \quad=$ jumalah responden

$\mathrm{Xy}=$ jumlah hasil perkalian antara skor $\mathrm{x}$ dan skor $\mathrm{y}$

$\mathrm{X}=$ jumlah skor seluruh $\mathrm{x}$

$\mathrm{Y} \quad=$ jumlah skor seluruh $\mathrm{y}^{3}$

Sebelum melakukan perhitungan untuk memperoleh angka indeks korelasinya (rxy) terlebih dahulu dikemukakan kembali hipotesis anternatif (Ha) dan hipotesis nihil $\left(\mathrm{H}_{0}\right)$, sebagai berikut:

\footnotetext{
${ }^{3}$ Syofian Siregar, Statistik Terapan Untuk Perguruan Tinggi.... H.205
} 
Ha : Ada hubungan yang signifikan pembelajaran pendidikan agama islam terhadap pemahaman jiwa agama siswa.

$\mathrm{H}_{0} \quad$ : Tidak ada hubungan yang signifikan pembelajaran pendidikan agama islam terhadap pemahaman jiwa agama siswa.

Tabel 5.

Kerja Hubungan Pembelajaran Pendidikan Agama Islam Terhadap Pemahaman Jiwa Agama Siswa Kelas XI IPA

Di SMA Negeri 05 Bengkulu Selatan

\begin{tabular}{|c|c|c|c|c|c|}
\hline No & $\mathrm{X}$ & $\mathrm{Y}$ & $\mathrm{X}^{2}$ & $\mathrm{Y}^{2}$ & X.Y \\
\hline 1 & 60 & 52 & 3600 & 2704 & 3120 \\
\hline 2 & 59 & 56 & 3481 & 3136 & 3304 \\
\hline 3 & 60 & 42 & 3600 & 1764 & 2520 \\
\hline 4 & 46 & 40 & 2116 & 1600 & 1840 \\
\hline 5 & 60 & 40 & 3600 & 1600 & 2400 \\
\hline 6 & 45 & 41 & 2025 & 1681 & 1845 \\
\hline 7 & 60 & 42 & 3600 & 1764 & 2520 \\
\hline 8 & 58 & 39 & 3364 & 1521 & 2301 \\
\hline 9 & 59 & 40 & 3481 & 1600 & 2360 \\
\hline 10 & 47 & 41 & 2209 & 1681 & 1927 \\
\hline 11 & 60 & 39 & 3600 & 1521 & 2340 \\
\hline 12 & 46 & 40 & 2116 & 1600 & 1840 \\
\hline 13 & 47 & 39 & 2209 & 1521 & 1833 \\
\hline 14 & 58 & 41 & 3364 & 1681 & 2378 \\
\hline 15 & 47 & 42 & 2209 & 1764 & 1974 \\
\hline 16 & 48 & 39 & 2304 & 1521 & 1872 \\
\hline 17 & 48 & 41 & 2304 & 1681 & 1968 \\
\hline 18 & 47 & 40 & 2209 & 1600 & 1880 \\
\hline 19 & 59 & 52 & 3481 & 2704 & 3068 \\
\hline 20 & 46 & 52 & 2116 & 2704 & 2392 \\
\hline 21 & 46 & 39 & 2116 & 1521 & 1794 \\
\hline 22 & 59 & 39 & 3481 & 1521 & 2301 \\
\hline 23 & 46 & 40 & 2116 & 1600 & 1840 \\
\hline 24 & 60 & 40 & 3600 & 1600 & 2400 \\
\hline 25 & 46 & 52 & 2116 & 2704 & 2392 \\
\hline 26 & 42 & 52 & 1764 & 2704 & 2184 \\
\hline 27 & 60 & 54 & 3600 & 2916 & 3240 \\
\hline 28 & 60 & 39 & 3600 & 1521 & 2340 \\
\hline 29 & 60 & 39 & 3600 & 1521 & 2340 \\
\hline 30 & 60 & 40 & 3600 & 1600 & 2400 \\
\hline 31 & 45 & 52 & 2025 & 2704 & 2340 \\
\hline 32 & 39 & 54 & 1521 & 2916 & 2106 \\
\hline 33 & 44 & 52 & 1936 & 2704 & 2288 \\
\hline 34 & 46 & 40 & 2116 & 1600 & 1840 \\
\hline 35 & 45 & 54 & 2025 & 2916 & 2430 \\
\hline 36 & 46 & 53 & 2116 & 2809 & 2438 \\
\hline
\end{tabular}




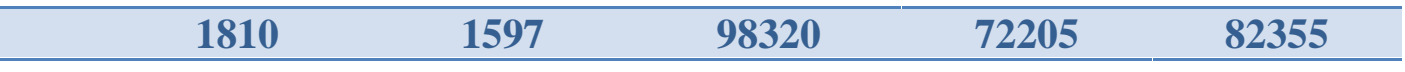

Diketahui:

$$
\begin{array}{ll}
\sum \mathrm{N} & =36 \\
\sum \mathrm{X} & =1810 \\
\sum \mathrm{Y} & =1597 \\
\sum \mathrm{X}^{2} & =98320 \\
\sum \mathrm{Y}^{2} & =72205 \\
\sum \mathrm{X} . \mathrm{Y} & =82355 \\
r x y & =\frac{n\left(\sum x \cdot y\right)-\left(\sum x\right)\left(\sum y\right)}{\sqrt{\left[n\left(\sum \mathbf{x}^{2}\right)-\left(\sum \mathbf{x}^{2}\right)\right]\left[n\left(\sum y^{2}\right)-\left(\sum y^{2}\right)\right]}} \\
= & \frac{36(82355)-(1810) \cdot(1597)}{\sqrt{\left\{36 .(98320)-(1810)^{2}\right\}\left\{36 .(72205)-(1597)^{2}\right\}}} \\
\hline \sqrt{\{3539520-3276100\}\{(2599380-2550409)\}} & \frac{74210}{\sqrt{\{263420\}\{48971\}}} \\
& =\frac{74210}{\sqrt{113577894}} \\
& =\frac{74210}{10657191} \\
& =0,696
\end{array}
$$

Dari perolehan korelasi di atas dijelaskan bahwa ada korelasi positif sebesar 0, 696 antara hubungan pembelajaran pendidikan agama islam terhadap pemahaman jiwa agama siswa kelas XI IPA di SMA Negeri 05 Bengkulu Selatan. Apakah koefisien korelasi hasil perhitungan tersebut signifikan atau tidak, maka perlu dibandingkan dengan tabel $r$ tabel, dengan taraf kesalahan di tetapkan 5\% (kepercayaan) dan $\mathrm{N}(36)$, maka $\mathrm{r}$ tabel $=0,329$.

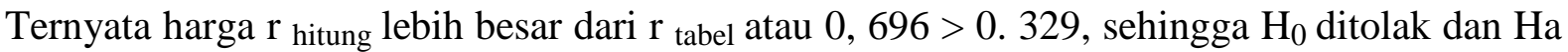
diterima.

\section{KESIMPULAN}

Setelah menganalisa data dari hasil penelitian, maka penulis dapat mengambil kesimpulan sebagai berikut:

1. Pembelajaran Pendidikan Agama Islam di SMA Negeri 05 Bengkulu Selatan adalah bahwa siswa yang menjawab baik sebesar 55,556\% dan 44,444\% dikategorikan sangat baik. 
2. Pemahaman Jiwa Agama Siswa di SMA Negeri 05 Bengkulu Selatan adalah bahwa siswa yang menjawab baik sebesar 66,667\% dan 33,333\% di kategorikan sangat baik.

3. Hubungan Pembelajaran Pendidikan Agama Islam Terhadap Pemahaman Jiwa Agama Siswa Kelas XI IPA di SMA Negeri 05 Bengkulu Selatan, berdasarkan hasil uji statistik dinyatakan terdapat korelasi yang signifikan. Hal ini terbukti dari perhitungan korelasi product moment yang diambil dari responden siswanya dengan nilai positif sebesar 0,696 dan bila dipersentasekan sebesar 48,4\% antara hubungan pembelajaran pendidikan Agama Islam terhadap pemahaman jiwa agama siswa di SMA Negeri 05 Bengkulu Selatan. Apakah koefisien korelasi hasil perhitungan tersebut signifikan (dapat digeneralisasikan) atau tidak, maka perlu dibandingkan dengan $\mathrm{r}$ hitung, dengan taraf kesalahan di tetapkan 5\% (kepercayaan) dan $\mathrm{N}$ (36), maka $\mathrm{r}_{\text {tabel }}=0,329$. Ternyata harga $\mathrm{r}$ hitung lebih besar dari $\mathrm{r}_{\text {tabel }}$ atau 0,696 > 0,329. Sehingga dapat disimpulkan bahwa $\mathrm{H}_{0}$ ditolak dan Ha diterima, artinya ada hubungan antara pembelajaran pendidikan Agama Islam terhadap pemahaman jiwa agama siswa kelas XI IPA di SMA Negeri 05 Bengkulu Selatan.

\section{DAFTAR PUSTAKA}

Ahmad, J. (2018). Paradigma pendidikan Islam: Upaya Mengefektifkan Pendidikan Agama Islam di Sekolah. In Pasca Sarjana UIN Syarif Hidayatullah.

Arif, M. (2011). Pendidikan Agama Islam inklusifmultikultural. Jurnal Pendidikan Islam. https://doi.org/10.14421/jpi.2011.11.1-18

Arikunto, S. (2010). Prosedur Penelitian Ilmiah. In Rineka cipta, Jakarta.

Diananda, A. (2019). Psikologi Remaja dan Permasalahannya. Journal ISTIGHNA. https://doi.org/10.33853/istighna.v1i1.20

Hakim, L. (2012). Model Integrasi Pendidikan Anti Korupsi dalam Kurikulum Pendidikan Islam. Taklim.

Hamzah, N. (2015). Pendidikan Agama Dalam Keluarga. At-Turats. https://doi.org/10.24260/at-turats.v9i2.315

Hendriana, E. C., \& Jacobus, A. (2017). Implementasi Pendidikan Karakter Di Sekolah Melalui Keteladanan Dan Pembiasaan. JPDI (Jurnal Pendidikan Dasar Indonesia). https://doi.org/10.26737/jpdi.v1i2.262

Jannah, M. (2017). Remaja dan Tugas-tugas Perkembangannya dalam Islam. Psikoislamedia : Jurnal Psikologi. https://doi.org/10.22373/psikoislamedia.v1i1.1493 
Mustafa, M. (2016). Perkembangan Jiwa Beragama Pada Masa Dewasa. Jurnal edukasi: Jurnal Bimbingan Konseling. https://doi.org/10.22373/je.v2i1.692

Nasrudin, M. (2017). Perkembangan Remaja. Journal Institutional Repository of IAIN Tulungagung (IRIT).

Nidawati. (2013). Belajar dalam Perspektif Psikologi dan Agama. Pionir.

Nurmadiah, N. (2016). Kurikulum Pendidikan Agama Islam. Al-Afkar: Jurnal Keislaman \& Peradaban. https://doi.org/10.28944/afkar.v2i2.93

Nyumirah, S. (2013). Peningkatan Kemampuan Interaksi Sosial (Kognitif, Afektif Dan Perilaku) Melalui Penerapan Terapi Perilaku Kognitif Di Rsj Dr Amino Gondohutomo Semarang. Keperawatan Jiwa.

Raharjo, S. B. (2010). Pendidikan Karakter Sebagai Upaya Menciptakan Akhlak Mulia. Jurnal Pendidikan Dan Kebudayaan. https://doi.org/10.24832/jpnk.v16i3.456

Soebiantoro, J. (2017). Pengaruh Edukasi Kesehatan Mental Intensif Terhadap Stigma pada Pengguna Layanan Kesehatan Mental. INSAN Jurnal Psikologi Dan Kesehatan Mental. https://doi.org/10.20473/jpkm.v2i12017.1-21

Sugiyono. (2018). Metode Penelitian Kombinasi (mixed Methods). In Alfabet.

Suharsimi. (2013). Metodelogi Penelitian, Suatu Pengantar Pendidikan. In Rineka Cipta, Jakarta.

Syafe'i, I. (2015). Tujuan Pendidikan Islam. Jurnal Usuluddin.

Wedan, M. (2016). Pengertian Pendidikan dan Tujuan Pendidikan Secara Umum. Silabus. 